\title{
PRISEGA KAO DOKAZNO SREDSTVO U VINODOLSKOM ZAKONU
}

Izv. prof. dr. sc. László Heka*
UDK: 34(497.5 Vinodol)(093)"1288" https://doi.org/10.30925/zpfsr.41.2.6

Ur.: 23. studenog 2019.

Pr.: 23. lipnja 2020.

Pregledni rad

\section{Sažetak}

Vinodolski zakon najstariji je hrvatski i jedan od najstarijih pisanih slavenskih zakona. Donesen je na blagdan Sveta tri kralja ili Bogojavljenje u utorak 6. siječnja 1288. Njegova je osobitost u tome što nije nastao voljom vladara ili feudalnoga gospodara, nego dogovorom vinodolskih općina i kneza, pa je u biti popis lokalnoga običajnog prava. Napisan je glagoljicom na hrvatskom jeziku. Poseban je i po pravnom sadržaju, napose jer osim odredaba nasljednoga, kaznenog $i$ postupovnog prava, uređuje i pitanja upravnoga prava. Premda obuhvaća i njemačke, talijanske, odnosno slavenske pravne institute, ipak je Vinodolski zakon nositelj hrvatskoga nacionalnog identiteta. Zbog toga ga se ne promatra samo kao jedan od glavnih izvora prava, nego i kao svjedoka hrvatskoga jezika, pisma i kulture. Iz više ga je aspekata opravdano uvrstiti među stožerne europske srednjovjekovne pravne propise pisane materinskim jezikom, uz Zakon sudnjii ljudem, Ruskaju Pravdu ili, Sachsenspiegel, odnosno još ranije (601.-925.) nastali anglosaksonski zbornik običajnoga prava. U radu se istražuje prisega kao dokazno sredstvo u parničnom postupku i načinom kako je regulirana Vinodolskim zakonom. Također se daje i usporedna analiza ovoga načina dokazivanja sukladno s odredbama drugih onodobnih slavenskih zakona.

Ključne riječi: Vinodolski zakon; dokazni postupak; kazne; prisega (rota); porota; suprisežnici.

\section{1. $U V O D$}

Budući da je objavljivanju Vinodolskog zakona (dalje: VZ) prethodila narodna skupština predstavnika vinodolskih općina, Bogović pretpostavlja da je ona održana u nedjelju 4. siječnja 1288. ,nakon mise pred novljanskom župnom crkvom, na istome mjestu gdje se crkva i danas nalazi”.' Zakon ne poznaje institut „Božjeg suda”, ni

* Dr. sc. László Heka, izvanredni profesor, Pravni fakultet Sveučilišta u Szegedu, Institut za poredbeno pravo i pravnu teoriju; heka@juris.u-szeged.hu.

1 Mile Bogović, Vinodol i njegova Crkva od Vinodolskoga zakona do naših dana (Rijeka: Riječka nadbiskupija, 2015.), 15. 
torturu koji su tada u Europi primjenjivani u dokaznom postupku. ${ }^{2}$ Propisuje pravnu jednakost svih stanovnika Vinodola. Rukopis VZ se do 19. stoljeća čuvao u Modruškom kaptolu u Novom Vinodolskom, 1851. je premješten u Narodni muzej u Zagrebu pa u Nacionalnu i sveučilišnu knjižnicu. Njegov su tekst Kostrenčić i Margetić podijelili na 75, Jagić, Rački i Barada na 77, a A. Mažuranić na 76 članaka. Prvi je put tekst uredio i objavio A. Mažuranić 1843. u zagrebačkom časopisu Kolo. ${ }^{3}$ Tada je izazvao veliku pozornost u znanstvenoj javnosti koja je s velikim zadovoljstvom primila na znanje činjenicu o postojanju samostalnoga, od rimskoga prava različitog, srednjovjekovnoga slavenskog prava. ${ }^{4} \mathrm{U}$ mađarskoj historiografiji ga se gdjekad naziva statutom, a ne zakonom, premda se u slavenskim jezicima riječ zakon pojavljuje već u 10. stoljeću na području današnje Ukrajine u obliku ,zakana”, a označavala je pravne običaje.

\section{KAZNE U VINODOLSKOM ZAKONU}

Kao rezultat dogovora između kneza i predstavnika devet općina (Novi, Ledenice, Bribir, Grižane, Drivenik, Hreljin, Bakar, Trsat, Grobnik) VZ je popisao tada već postojeće pravne običaje. Neke od njih je izostavio, jer su bili zastarjeli ili nisu odgovarali interesima mjesnoga stanovništva, odnosno knezovima Frankopanima, a neke je pak preformulirao. Zakon je uveo podjelu mjesnoga pučanstva na povlašteni sloj (knez, članovi njegove obitelji, službenici, oružana pratnja i svećenstvo), na predstavnike općine (satnik, grašćik i busović), odnosno na kmetstvo. Čl. 70. propisano je kako knez upravlja Vinodolom na „temelju prirodnog prava” te da u odnosu na ,izdajice” ima pravo raspolaganja njihovim životima i imovinom. U tom je slučaju mogao ostvariti i pravo na osvetu (mašćenje prema ruskoj riječi mšćenie). Čl. 57. strogo je zabranio održavanje kmetskoga sabora bez nazočnosti kneževih predstavnika. Iz kazne (zapljene cijele imovine) je razvidno kako je knezu bilo jako stalo spriječiti održavanje takvih zborova njemu iza leđa. Ista je ova sankcija predviđena i za lažno predstavljanje pristavom. Knez je odlučivao o životima onih Vinodolaca koji nisu mogli isplatiti novčanu kaznu (čl. 74.), a to nije bio rijedak slučaj. ${ }^{5}$ Svaki je stanovnik Vinodola morao knezu dati dio svoga uroda (učestje) te je bio obveznik i drugih davanja.

O društvenoj polarizaciji stanovništva svjedoče i kazne (uglavnom novčane) za pojedina djela. Za ubojstvo ili napad na život kneza, članova njegove obitelji,

2 Vidi Lujo Margetić, „Hrvatski pravni običaji”, Arhivski vjesnik br. 37 (1994): 147-159.

3 Antun Mažuranić, „Zakon vinodolski od lěta 1280.”, Kolo knj. 3. (1843): 50-97.

4 Vidi inter alia: Osip Bodjanski, Vinodol'skyj zakon 1280. g. v podlinnike-perevod s serbskago (Moskva: Ćtenija v Imperatorskom Obščestve istorii i drevnostej pri Moskovskom universitete, 1846.); Fedor Breitenfeld, Dva poljska prijevoda Vinodolskoga zakona, 1856. i 1935. (Zagreb: 1936.); Vatroslav Jagić, Zakon vinodol'skij, podlinnyj tekst s russkim perevodom, kritičeskinii zamečanljami i objasnenijami (Sankt Peterburg: Obščestvo ljubitelej drevnej pis'mennosti, 1880.); Lujo Margetić, Iz vinodolske prošlosti. Pravni izvori i rasprave (Rijeka i Zagreb: Liburnija i Školska knjiga, 1980.); Lujo Margetić, Vinodolski zakon 1288-1988 (Novi Vinodolski: Mjesni odbor za obilježavanje 700. obljetnice Vinodolskog zakona, 1987.); Matko Laginja, Vinodolski zakon. Pravo III (1875.).

5 Marko Kostrenčić, Nacrt historije hrvatske države i hrvatskog prava (Zagreb: Školska knjiga, 1956.), 196. 
odnosno njegovih službenika bila je propisana krvarina ( $v r a z ̌ d a)$. Ubojstvo se kmeta kažnjavalo novčanom kaznom od 100 libara, za što se u to vrijeme moglo kupiti 12 komada stoke. Ako je ubojica uhvaćen, onda je oštećenikova obitelj imala pravo na krvnu osvetu (čl. 29.). Pokušaj ubojstva kneževa službenika kažnjavan je novčanom kaznom u iznosu od 50 libara. Počinitelj krađe trebao je platiti sedmerostruki iznos ako je stvar otuđena od člana povlaštenoga sloja, s dvostruki iznos ako je otuđena od svećenika, predstavnika općine ili kmetova (čl. 35. i 36.). ${ }^{6}$

Ženska čast bila je posebno zaštićena. Za silovanje je bila propisana novčana kazna istovjetna iznosu krvarine (100 libara), od čega je 50 libara trebalo platiti ženi te isto toliko i knezu. Polovina krvarine bila je popisana ako je muškarac osramotio ženu time što joj je strgnuo vrpcu ili rubac s glave proglašavajući je time nepoštenom (čl. 27.). Kazna je bila znatno blaža ako ovo djelo nije počinila muška, nego ženska osoba.

\section{PRISEGA KAO DOKAZNO SREDSTVO SREDNJEVJEKOVNOGA PRAVA}

Prisega je svečana izjava kojom neka osoba svjedoči istinitost nekoga iskaza ili obećanja. Može biti izjavna (lat. iuramentum assertorium) kojom se potvrđuje neka izjava o činjenicama koje su predmet dokazivanja ili obećajna (lat. iuramentum promissorium) kojom se posvjedočuje istinitost obećanja. ${ }^{7}$ Bila je dokazno sredstvo u sudskim sporovima koji su se odvijali prema običajnome pravu u koje je preuzeta iz kanonskoga prava. Prisutna je donekle i danas u dokaznom sustavu rimskokanonskoga procesnog prava.

Sukladno s kanonskim pravom tuženik u građanskom i optuženik u kaznenom postupku mogli su neutralizirati opterećujuće manjkave dokaze prisegom očišćenja (lat. iuramentum purgationis ili purgatorium), a sudac je mogao odrediti prisegu za dokazivanje neke činjenice (lat. iuramentum revelatorium). Stranka se mogla sama ponuditi zaprisegnuti (lat. iuramentum oblatum) i mogla je drugoj stranci ponuditi polaganje prisege (lat. iuramentum delatum). Prisega koju joj je druga stranka ponudila natrag zvala se iuramentum relatum, a ona koja je meritorno odlučila ishod spora bila je iuramentum decisorium. U formalnom pogledu prisegnuti se trebalo dodirivanjem evanđelja ili svete relikvije (lat. juramentum corporaliter praestare). ${ }^{8}$

U crkvenopravnom pogledu da bi prisega bila važeća morala su biti ostvarena tri uvjeta: lat. judicium in jurante (prisega mora biti sveobuhvatna i slobodno dana), lat. veritas in mente (volja za svjedočenjem istine), lat. iustitia in objecto (punovažna je

6 Josip Bratulić, ur., Vinodolski zakon 1288. faksimil, diplomatičko izdanje, kritički tekst, tumačenje, rječnik (Zagreb: Nacionalna i sveučilišna biblioteka, JAZU, Pravni fakultet Zagreb, Globus, 1988.), 7-8.

7 Dominik Budrović, O. P., „Da li je kriva zakletva uviek težak grieh“, Bogoslovska smotra 31, 1 (1943): 49-58., pristup: 29. kolovoza 2018., file://C:/Users/Felhaszn\%C3\%A11\%C3\%B3/ Downloads/BS_1_43_Budrovic.pdf.

8 László Heka, „Der „Eid” im Beweisverfahren der südslawischen Region“ (Vergleichende Studie), u: Legal Transitions. Development of Law in Formerly Socialist States and the Challenges of the European Union. (Szeged: Pólay Elemér Alapítvány Könyvtára, 2007.), 115122. 
samo prisega u pravednoj stvari). Ovaj posljednji uvjet znači da prisega ne može biti usmjerena protiv vjere, morala i dostojanstva, niti se njome smije povrijediti pravo treće osobe.

Strogo je kažnjavano krivokletstvo (lat. periurium) kao svjesno iznošenje laži, dok je lažno obećanje (lat. periuratio) značilo nepridržavanje položene prisege.

Prisega se je primjenjivala, samo ako se meritorna činjenica nije mogla dokazati na drugi način. Isključeni od prisege bili su maloljetnici, osobe s mentalnim poteškoćama te osobe osuđene za kazneno djelo počinjeno iz koristoljublja ili zbog lažnoga svjedočenja.

U rimskom pravu prisega je bila predviđena i u parničnom i u izvanparničnom postupku, odnosno u izvansudskom postupku (lat. ius iurandum extra ius et extra iudicium). U parničnom postupku su postojale prisege in iure (polagala se na početku spora pred pretorom, a ako je stranka odbila prisegnuti, onda se to smatralo priznanjem te je spor već u početnoj fazi bio riješen) i in iudicio (u dokaznom postupku). Ova je potonja polagana u usmenom sudskom sporu u kojemu je presudu donosila porota $\mathrm{i}$ bila je različita od prisege in iure. Naime, ako porotnici neku činjenicu nisu smatrali dostatno dokazanom, onda je porota prije donošenje konačne odluke obvezala jednu od stranaka na polaganje prisege. ${ }^{9}$ Dosuđena prisega polagala se uz određene formalnosti na za to predviđenome mjestu (u crkvi, kapeli, pred izaslanikom vjerodostojnoga mjesta) i u dogovoreno vrijeme. ${ }^{10}$

Ako su se obje stranke poslužile prisegom ostala je neizvjesna situacija u kojoj su oprečne prisege dviju stranaka stajale međusobno suprotstavljene, pa su se tada na njihov poziv mogli pozvati suprisežnici (lat. conjuratores, consacramentales) kao pomagači u prisezi. (Eideshelfers). Suprisežnici ili porotnici (obično njih dvanaest) svečano su polagali dosuđenu prisegu u nazočnosti prisežnika. Oni nisu prisegli o činjenicama o kojima imaju saznanja, nego svjedočeći istinitost prisege stranke u postupku s kojom su zajedno prisegli (zato je njezin naziv: prisega očišćenja). Suprisežnici su morali biti punoljetni, pošteni i vjerodostojni pripadnici staleža kojemu je pripadao i prisežnik. Tako je u sporu između plemića suprisežnik mogao biti samo plemić koji je imao svoj posjed. S obzirom na to da je njihova vjerodostojnost počivala na staleškom rangu, tako je broj suprisežnika ovisio o vrijednosti spora. U parnicama vezanima za ubojstvo, nasilje itd. vrijednost spora utvrđivala se na temelju krvarine (vražde) koja je bila mjerodavna za određivanje broja suprisežnika.

Pretpostavlja se da je slijedom prisege, zbog razvitka srednjovjekovnoga parničnog postupka, nastao institut porote, odnosno dokazivanje putem svjedoka $\mathrm{i}$ isprava. Naime, suprisežnici su u početku, samo potvrđivali prisegu stranke u postupku, ali se postupno tražilo da jedan njihov dio regrutira protivnik (što je već bila neka vrsta

9 U Ugarskoj je pitanje prisege regulirao Tripartit (Werbőczy: Hármaskönyv) u II. glavi § 27.-40., a u poslijenagodbenome razdoblju Zakon broj 1868. LIV. § 221.-244., Zakon broj 1881: LIX. § 21. i 22. i Zakon broj 1893: XVIII. § 100.

10 Za razliku od ovoga parničnog postupka srednjovjekovni spor više nije ostavljao mogućnost za prisegu in judicio, jer je usmenu raspravu zamijenilo dokazivanje ispravama. Nadalje sudac nije čak ni vidio stranke, a po crkvenom je nauku prihvaćeno stajalište kako su neupitne činjenice na koje je stranka prisegnula. Zato nije mogla više postojati prisega o čijoj dokaznoj snazi sud slobodno odlučuje. 
porote), a zatim i da prisežu isključivo o onome što im je poznato iz vlastitog iskustva. Kada je svjedočenje o vjerodostojnosti stranke zamijenilo svjedočenje o relevantnim činjenicama, nastalo je dokazivanje putem svjedoka.

Porota je bila zamjena za, tzv. Božji sud (dokazivanje putem usijanoga željeza, ključale vode, ili potapanja u vodu, sudskoga dvoboja itd.). Naime, Katolička Crkva na Lateranskom saboru 1215. ukinula je ovaj način dokazivanja i zamijenila ga je prisegom. Općenito se smatra da je riječ o ustanovi anglosaksonskoga prava, u kojoj su postajali i suprisežnici kao dokazno sredstvo, ali i porota kao sudbeno tijelo sa zadaćom utvrđivanja krivnje. ${ }^{11}$ Ova su dva instituta u engleskom pravnom sustavu opstala sve do polovice 17. stoljeća od kada postoji samo porota (engl. jury), dok je u kontinentalnom dijelu Europe prisega kao dokazno sredstvo opstalo još i u 18. stoljeću. Prisega očišćenja na području Habsburške Monarhije primijenjivala se i nakon toga o čemu svjedoči ugarski Zakon br. 27. iz 1729. Ipak je poslije uvođenja Praxisa criminalisa Ferdinanda III. 1656. ona postupno napuštana prepuštajući mjesto vezanom dokaznom sustavu (svjedoci, isprave, pisani dokazi). Nakon Francuske revolucije porotno je suđenje preuzeto iz engleskoga prava i u kontinentalnoj Europi. Tako je u kaznenim predmetima sud bio sastavljen dijelom od profesionalnih sudaca, a dijelom od građana (laika, porotnika), s tim da su ovi potonji sudjelovali samo kao povremeni suci. Profesionalni sudac kao predsjednik vijeća vodio je javnu kontradiktornu raspravu, a zatim je porota odlučivala o činjeničnim pitanjima, a napose o tomu je li optuženik kriv. No, u odmjeravanju kazne i u pravnim pitanjima odlučivao je isključivo sud, a ne porota. U 19. stoljeću su nastali sudovi u kojima su u prvom stupnju suci i porotnici zajedno odlučivali o svim pitanjima. Takvi sudovi uz sudjelovanje građana, sude i danas u mnogim europskim zemljama. No, u postupku po žalbama uglavnom odlučuju vijeća sastavljena od profesionalnih sudaca. U anglosaksonskom pravu (Velika Britanija, SAD) porotni je sustav nešto drukčiji. ${ }^{12}$

Porota i dokaz svjedocima i ispravama nastali su na tragu prisege putem razvitka srednjovjekovnoga parničnog postupka. ${ }^{13}$ Naime, suprisežnici su u početku, samo potvrđivali prisegu stranke u postupku, ali se postupno tražilo da jedan njihov dio regrutira protivnik (što je bila neka vrsta porote), a zatim i da prisežu samo o onome što im je poznato iz vlastitog iskustva. Zasigurno je stranci u sporu bilo teško pronaći veći broj slobodnih ljudi koji će pod prisegom posvjedočiti njezine činjenične navode, iako o samome predmetu nisu imali relevantna saznanja. U samom je postupku vrlo važnu ulogu imao organ (sud) koji je odlučivao o tome koja je stranka dužna položiti prisegu, jer je njegova ,slobodna ocjena već obuhvatila određeno preduvjerenje o

11 Vidi: Tamás Antal, „The Legal Status of Judges in the German 'Spiegels' and in the Medieval English Common Law”, u: Schwabenspiegel-Forschung im Donaugebiet, hrsg. von Elemér Balogh. (Berlin: Walter de Gruyter, 2015.), 73-83.

12 Vidi: Attila Badó, Esküdtszéki itéletek (Szeged: Studio Batiq, 2004.); Gábor Feleky, János Lőrinczi i Attila Badó, „Empirijsko istraživanje porotnog sustava u Mađarskoj”, Zbornik Pravnog fakulteta Sveučilišta u Rijeci 39, br. 3 (2018): 1287-1318; Harry Kalven i Hans Zeisel, The American Jury System (New Haven: Yale University Press, 1966.).

13 Alen Uzelac, Istina u sudskom postupku (Zagreb: Pravni fakultet Zagreb, 1997.), 64-74, pristup 29. kolovoza 2018., http://www.alanuzelac.from.hr/pubs/D06Istina $\% 20 \% 20 u \% 20$ sudskom\%20postupku.pdf. 
činjenicama. Uzelac smatra da sastav angloameričkoga instituta porote ,asocira na kletvenike (compurgatores) koje su stranke mogle pozvati da zakletvom zajamče istinitost njihovih navoda. U oba slučaja riječ je o 12 osoba - laika, no dok kod kompurgacije njih biraju stranke, kod porotnog suđenja riječ je o, po definiciji, nepristranim osobama". ${ }^{14}$

Naziv porota koji se udomaćio u hrvatskom, srpskom, češkom i slovačkom pravu ima osnovicu u staroslavenskoj riječi rota u značenju prisega. Riječ je o suprisezanju (po-rota) određenoga broja osoba uz određenu procesnu stranku (uglavnom uz tuženoga) radi pobijanja tužiteljeva zahtjeva, poricanja njegovih činjeničnih navoda i dokazivanja istinitosti vlastitih.

\section{PRISEGA PO VINODOLSKOM ZAKONU}

Parnični je postupak u Vinodolu bio akuzatoran, usmen i javan. Pokretan je formalističkim pozivanjem optuženoga pred sud (,dvor”). Sudionici postupka bili su sud, tužitelj (obično oštećenik), optuženi, pristav (sudski službenik koji je provodio prethodni postupak), pozovnik (osoba koja poziva sudionike postupka na izjašnjavanje o nekim navodima ili činjenicama), pudar (bio je dužan prijaviti kazneno djelo, a u slučaju propusta te obveze čl. 23. ga je obvezivao na plaćanje globe u iznosu od deset libara), svjedok, odgovornik (odvjetnik) i porotnik. Mjesto presude u kaznenim predmetima bio je knežev dvor, dok su u građanskim parnicama možda postojali općinski sudovi (neki autori pretpostavljaju čak i u svih devet slobodnih općina) kao prvostupanjski sudski forumi. Ako ih je bilo, onda je „dvor” djelovao kao prizivni sud u tim sporovima.

Teret dokazivanja bio je na tužitelju. To je rješenje različito od tadašnjega srednjevjekovnog prava, a tuženik je imao pravo na odvjetnika ili odgovornika (na ovoga potonjega samo uz suglasnost suda). Odvjetnik je vjerojatno uz svoju zadaću obnašao i ulogu odgovornika, dakle odgovarao je na navode tužitelja. U dokaznom su postupku glavno dokazno sredstvo bili svjedoci (i žene, ako nije bilo muških svjedoka). Ako ih nije bilo onda je slijedila prisega, odnosno isprave i pudari (stražari nad vinogradima, zemljama i gumnima čije se svjedočenje smatralo vjerodostojnim).

Tužitelj je nastojao osigurati svjedoke, jer je u protivnom uglavnom bila tuženome dosuđena prisega s pomoću porotnika, kojom se mogao očistiti od sumnje. To je bilo vrlo povoljno rješenje za tuženika, pa se nije koristio mogućnosti da ponudi protusvjedoke koja je propisana čl. 47. Kod svjedočenja je bitan element bio klič, naime povik pomagajte, kako bi netko uhvatio počinitelja, ali i kao javno upućivanje na počinjenje protupravnoga djela. Uzvikivaču se vjerovalo, ako je prisegnuo pred sudom, da je prepoznao počinitelja. Zakon ga spominje u čak pet članaka iz čega se može zaključiti kako je ovaj vid dokazivanja bio čest, premda je bio relevantan, samo ako nije bilo drugih svjedoka.

Prisega se primjenjivala samo onda, ako nije bilo svjedoka i bila je uobičajeni način dokazivanja uglavnom kod tuženika, osim kod kaznenoga djela silovanja u kojem je tužiteljica prisezala u istinitost svojih tvrdnji. Prisegu su davali i porotnici

14 Uzelac, Istina u sudskom postupku, 85-107. 
(od pet do 49), koji su u korist optuženoga (u slučaju silovanja tužiteljice) svjedočili o nevinosti obveznika prisege. U njihovu nedostatku prisegnuo je on sam onoliko puta koliko mu je nedostajalo porotnika. S tim u svezi čl. 10. propisuje ako ih (tj. porotnika) ne more imiti ili ako porotniki nima, vola ih toliko ne more imiti (čl. 56.), odnosno ako porotniki nima (čl. 68.), onda je stranka (ili neki od njezinih porotnika) prisegla do propisanoga broja prisege. ${ }^{15}$

Broj je porotnika bio razmjeran težini djela, pa je kod kaznenog djela ubojstva trebalo njih 49, kod drugih teških kaznenih djela 24 , za srednje teška djela njih jedanaest te naposljetku samo pet kod lakših djela. S obzirom na to da su porotnici prisezali u korist tuženikove nevinosti, vjerojatno su bili njegovi srodnici. No, kod teških kaznenih djela bilo je teže pronaći veliki broj suprisežnika, pa je tada često tuženik sam polagao potreban broj prisega umjesto porotnika. VZ nam otkriva da je porotnike angažirao tuženik (neka sebi nađe porotnike, kako bolje vi) i da ih se plaćalo (ako bi netko obećao prisegnuti, a zatim je odustao, morao je platiti iznos koji je teretio optuženika), da se prisega polagala izvan suda, vjerojatno na glavnom gradskom trgu kako bi joj nazočili građani i tako je legitimirali. Način polaganja prisege opisan je u već spomenutom slučaju silovanja (čl. 56.). Ako nije bilo svjedoka oštećenica se smatrala „vjerodostojnom” te je trebala na svojoj strani imati 25 suprisežnica, isključivo ženskih osoba (ili sama prisegnuti do toga broja prisega). Tužiteljica je prisegnula stavljajući ruku na Evanđelje. Prisižući dakle s njom, imaju taknuti ruku $i$ govoriti u tu prisegu. A svi njezini porotnici imaju biti žene. A koja se ondje zaprisiže, njezin odgovornik ima odgovoriti: 'Da, s onom prisegom i ja prisižem'. A ona ima priseći kako je zgora rečeno. A ako bi ta žena ili koji od njezinih porotnika pogriješili u čemu, što je gore rečeno: onaj protiv koga govori (koga tuži op. aut.) neka bude odriješen od grijeha (zločina - op. aut.) više rečenoga. ${ }^{16}$

Postojala je i zakonska mogućnost oslobađanja od prisege na običnom mjestu, gdje se prisege polažu u nazočnosti dvorskoga pouzdanika i to ako se prisiže za malu stvar. Oslobođenik od prisege trebao je tada platiti iznos koji je bio predmet spora, a sve je druge porotnike mogao otpustiti bez ikakve naplate, jer je cijela vrijednost spora već bila isplaćena (čl. 69.).

Prisega se u VZ prvi put spominje u čl. 7. u svezi sa svjedočenjem osoba koje su tijekom provalne krađe počinjene u gradu, pozivale u pomoć (klicale). Ako je sam oštećeni klicao pomagaj tijekom hvatanja počinitelja in flagranti, onda je prisegom trebao samo potvrditi krivnju osumnjičenoga, naime, da je zlotvorca prepoznao. Sankcija za ovo djelo bila je novčana kazna u iznosu od 50 libara u korist kneza te je počinitelj bio obvezatan nadoknaditi dvostruki iznos štete. Međutim, ako se ovo pozivanje nije oglasilo (dakle, ako nije klicano), onda je počinitelj bio dužan platiti samo 40 soldina i štetu nanesenu oštećeniku. Istovjetna je kazna bila predviđena za isto zlodjelo učinjeno danju, ako je bilo dokazivo po vjerodostojnu svjedoku. Klič pomagaj bio je vjerodostojan i u slučaju noćne krađe (živine u staji, žita na gumnu

15 Lujo Margetić, Vinodolski zakon 1288-2018., 3. izd. (Novi Vinodolski: Naklada Kvarner, 2018.), 114.

16 Tekst VZ, pristup 31. kolovoza 2018., https://www.pravo.unizg.hr/_download/repository/ Vinodolski_zakonik\%5B1\%5D.pdf. 
ili meda), za što je kazna iznosila 50 libara, dok je 40 soldina bila kazna za isto djelo počinjeno danju, ako kliča nije bilo. Štetu je također trebalo platiti u dvostrukom iznosu (čl. 7.-8.).

Prisega se uz porotnike kao dokazno sredstvo (osumnjičenoga) spominje u čl. 9. za kazneno djelo nasilja ili krađe, kada tužitelj nije imao dokaza protiv krivca. Tada je kod kaznenog djela nasilja osumnjičeni trebao prisegnuti zajedno s dvadesetčetvoricom porotnika. Kod djela krađe trebalo je prisegnuti njih dvanaest, uz uvjet da je zbog kaznenoga djela pretrpljena šteta i da se ondje klicalo pomagaj. Samo šest prisežnika tražilo se u slučaju krađe u mošuni, za požeg žita, što stoji na polju i za krađu sijena u stogu noću. ${ }^{17}$ Ako si prisežnik nije uspio pronaći porotnike, onda je on sam prisegnuo toliko puta koliko mu je suprisežnika nedostajalo (čl. 10.). Za nasilje u vinodolskom pristaništu propisana je novčana kazna (imala se platiti knezu) u iznosu od 50 libara, a za krađu 24 libre neovisno je li kazneno djelo počinjeno danju ili noću. Ako nije bilo svjedoka, osumnjičenik je trebao osobno prisegnuti dok nije ispunjen propisani broj od 12 prisega (čl. 11.). Prisega je propisana i u čl. 27., određujući da se za osramoćivanje žene zbacivanjem njezina pokrivala s glave (hovrlice ili pokrivače) trebala platiti novčana kazna u iznosu od 50 libara, ako je počinitelj bio muškarac (od toga je iznosa 48 libara pripadalo osramoćenoj ženi), a ako je počiniteljica bila žena ona je plaćala dvije libre dvoru i dvije ovce tužiteljici. ${ }^{18}$ Ovaj čin sramoćenja dokazivali su iskazi „tri dobra muža ili žene”, a ako nije bilo svjedoka imao je prisegnuti „onaj koji taji” i bio bi slobodan od svake krivnje. Ključari i krčmari, odnosno podružnici (koji prodaju tuđe vino) također su bili obveznici prisege. Bez vjerodostojnih svjedoka nije se vjerovalo ključaru da je nekomu dao, darovao ili posudio nešto. Ako vrijednost spora nije dostizala 20 soldina, onda je umjesto svjedoka bila prihvaćena njegova prisega taknuv sveto Evanđelje (čl. 42.). Krčmar je svaku prodaju vina na veresiju iznad iznosa od deset soldina morao dokazivati svjedocima. Ispod je toga iznosa prisegnuo isto kao i podružnik za iznos do 50 soldina (čl. 43.). Vjerodostojnost trgovačkih knjiga dokazivala se svjedocima, dok je prisega nad Evanđeljem bila dostatan dokaz za iznos od 50 libara (čl. 44.). Namjerno prouzročena vidljiva tjelesna ozljeda (zlonamjerno uzrokovana krv) smatrala se vjerodostojno dokazanom, ali ako za njezino nanošenje nije bilo svjedoka, onda se tražila oštećenikova prisega (čl. 64.).

Za ubojstvo kao najteže kazneno djelo propisano je 50 prisega na okrivljenikovoj strani (čl. 68.), prisegnuti je morao i poslanik (čl. 72.), osim ako ga je poslao dvor ( $a$ taj se poslanik hrvatski zove 'arsal'), odnosno pozovnici i kmetovi pozivani pred dvor (čl. 73.).

U dodatku poslije zadnjega 75. članka navodi se da u parnicama u svezi s nekretninama (imanja, vinograda, zemlje, kuće, vrta) svjedoci vjerodostojno dokazuju tuženikovu tvrdnju da je posjed kupio ili da mu je dan, odnosno darovan. Tuženik je

17 Tekst zakona iz: Marko Kostrenčić, „Vinodolski zakon”, Rad JAZU 227, Razredi filologičkohistorički i filosofičko-juridički, knj. 99 (1923): 163 (54)-176 (67).

18 Čl. 27. „Ošće: ako bi muž ženi zvergal hoverlicu ili porivaču z glave va zli voli, ter bi se moglo prikazati trimi dobrimi muži vola ženami, plati libar 50 ako je tužba s toga, od kih gospodin knez imi soldini 40, ona koj je vašćina učinena 40 i 8 libar. Da ako žena ženi sverže pokrivaču više rečenu, plaća 2 libre dvoru, a onoj 2 ovci; ako ubo onde nisu svedoci dobri prisezi, ki taji da ni to učinil, budi prost". 
morao prisegnuti i sljedećim riječima: pred onim svjedocima bilo je to, kako je gore rečeno. Nakon toga je svoj posjed slobodno uživao.

Pozornost privlači novo tumačenje načina primjene prisege koje donosi Bartulović. Upućuje na to da VZ nije poznavao ni Božji sud, tj. ordaliju, ni torturu kao dokazno sredstvo, nego je uz priznanje i svjedoke, postojala i prisega s određenim brojem, tzv. porotnika iz šire obitelji, ovisno o težini djela. Optuženik za razbojstvo dokazivao je nevinost prisegom s 24 porotnika, a za krađu s 11 (čl. 9.). Jedino je kod silovanja pravo na prisegu imala tužiteljica uz 24 porotnice (čl. 56.), a kod ranjavanja do krvi žrtva (čl. 64.). Bartulović ove odredbe objašnjava time što se pretpostavlja da žena neće zlonamjerno, lažno prijaviti silovanje i izložiti tako se javnosti. Zbog toga se ženi na dobrom glasu vjerovalo kada je prijavila silovanje. Za osobu ranjenu do krvi također se pretpostavljalo da ne bi sama sebi nanijela takvu ranu, samo da bi nekoga lažno prijavila. Po njemu je neobična odredba (čl. 10. i 56.) da optuženi koji nema dostatno porotnika može sam dati prisegu za onoliko porotnika koliko mu nedostaje, jer to može iskoristiti beskrupulozni zločinac koji će bezobzirno prisegnuti u svoju korist. ${ }^{19} \mathrm{~S}$ tim u vezi postavlja pitanje je li to smisao dokazivanja prisegom i osobito samoprisegom? Po njemu bi se postupak koji predviđa VZ mogao shvatiti tako da suci donose presudu na temelju činjenica i svjedoka. Sud je oslobodio optuženika, ako tužitelj nije dokazao počinjenje djela s njegove strane. No, ako nevinost optuženika nije neprijeporna, onda suci u Vinodolu nisu bili voljni preuzeti odgovornost i osloboditi tuženoga. Umjesto toga su mu dodijelili pravo na prisegu s porotnicima, odnosno samoprisegu prije negoli su ga oslobodili. Tako odgovornost pada na njega, a u slučaju mogućih novih dokaza protiv njega, ponovno je odgovarao za djelo, ali i za krivokletstvo. ${ }^{20}$

\section{USPOREDBA S DRUGIM ZAKONIMA SLAVENSKIH NARODA}

U vrijeme nastanka VZ među slavenskim su narodima pravne odnose regulirali, npr. Ruskaja pravda, Zakon sudnjii ljudem, a nešto kasnije su nastali Zakonik cara Dušana, odnosno Poljički statut. ${ }^{21}$ Oni su uz recepciju bizantskoga prava ujedno bili i

19 Nešto slično nalazimo u islamskom pravu kod jednog oblika razvoda braka ( $l i$ 'an), kada muž optužuje ženu za brakolomstvo, a za to nema potrebna četiri svjedoka. Tada umjesto svjedoka on osobno priseže četiri puta. Isto toliko puta priseže i žena zaklinjući se da nije počinila preljub. Obje strane prisežu još jednom (peti put) zazivajući na sebe Božju kaznu ako ne govore istinu. Sud u tom slučaju izriče rastavu braka. No, kod tog oblika raskida bračne sveze, ponovno stupanje u bračni odnos između tih dviju osoba više nije moguć, za razliku od svih drugih oblika rastave braka. László Heka, Vallási jogrendszerek (Szeged: Pólay Elemér Alapítvány Tansegédletei, 2012.), 314-315.

20 Željko Bartulović, „Pravna ostavština”, u: Putovima Frankopana, Frankopanska baština u Primorsko-goranskoj županiji, ur. Ines Srdoč Konestra i Saša Potočnjak (Rijeka: Primorskogoranska županija, 2018.), 427-428.

21 Zakon sudnjii ljudem (Sudski zakon za ljude) najstariji je slavenski pravni zbornik. Smatra se da je nastao nakon pokrštavanja Bugara (865.), ili za cara Borisa (853.-889.), ili pak njegova sina Simeona (893.-927.). Neki osporavaju da je riječ o zbirci bugarskoga običajnog prava, nego tvrde da je bizantski ili moravski pravni propis. Srpski istraživači smatraju da je nastao u Panoniji te je poslije u Moravskoj doživio dopune, a potom su ga preuzeli Rusi i drugi Slaveni. 
zbirke slavenskoga običajnog prava. ${ }^{22}$

\subsection{Kolektivna odgovornost}

Slaveni su dugo vremena zadržali kolektivno vlasništvo koje se kod južnih Slavena nazivalo plemenšćina ili plemenita zemlja, a unutar pojedinoga roda se zajednička zemlja nazivala obščina, opština, općina. Ruskaja pravda za kolektivitet koristi naziv verv, što je označavalo teritorijalnu jedinicu, ali i krvno srodstvo. Iz zajedničkoga vlasništva proizlazila je i kolektivna odgovornost za kaznena djela (ubojstva) počinjena u pojedinoj zajednici. Dakle, za zločin počinjen na njegovu području ili su ga počinili njegovi pripadnici verv je bio dužan platiti propisani iznos viru, koju VZ propisuje pod nazivom krvarina, a kao kolektivna financijska obveza spominje se još i kao vražda, wrožda, wrožba, wrož. Ovaj staroslavenski naziv danas je očuvan još samo kod Čeha kao naziv za ubojstvo. Ruskaja pravda i VZ razlikovali su se od drugih slavenskih zakona po tome što su u njima prevladavale novčane kazne, a krvna je osveta ( vražda) u Pravdi ukinuta već potkraj 11. stoljeća. ${ }^{23}$ Zajednica je bila oslobođena od odgovornosti, ako je kazneno djelo (ubojstvo) počinjeno bez razloga. Tada je općina trebala predati počinitelja vlastima. Visina iznosa ovisila je o tomu je li ubijen plemić, povlašteni član zajednice ili kmet. Verv ili općina su trebali pronaći počinitelja i izručiti ga vlastima ili su bili dužni isplatiti krvarinu. Dušanov zakonik

ZSLJ sadrži uglavnom kaznenopravne odredbe, ali uređuje i obiteljsko te nasljedno pravo, odnosno postupovno pravo. Tijekom kasnije redakcije zakon je podijeljen na 32 članka, od koji su 22 preuzeta iz bizantske Eklogae (deset od njih je doslovno prevedeno, a dvanaest je prerađeno). Ruska je redakcija znatno opsežnija i ima 77 (odnosno 83) članka. Karakteristike tadašnjega bugarskog prava su jednostavnost koja se ogleda u činjenici što kaznena djela nisu klasificirana prema vrstama, nadalje što su u zakonu zadržani elementi talionskoga prava (ius talionis) te su propisane drakonske kazne za pojedina kaznena djela, a vrlo je velika pozornost dana iskorjenjivanju slavenskih poganskih običaja. Vidi: Dragoslav Janković, Istorija država $i$ prava naroda Jugoslavije (Beograd: 1960.), 103.

22 Najpoznatiji slavenski zbornik običajnoga prava Ruskaja pravda nastao je u 11. stoljeću u dvije inačice. Vjerojatno je ranije nastala njegova kraća verzija (R. P kratkoj redakcii), dok je duža verzija ( $R$. P. prostrannoj redakcii) kasnijega datuma (12. stoljeće) i detaljizira odredbe kraće „redakcije”, ali i donosi neke nove. Zakonski je tekst prvi put publiciran 1767. Kraća Pravda obuhvaća tri dijela: Jaroslavovu Pravdu, vjerojatno iz 1016. (§ 1.-18.), Jaroslavićevu Pravdu (Jaroslavovih sinova) nastala između 1054. i 1076. (§ 19.-41.) te Pokon virni i Urok mostnjikam (§ 42.-43.). Šira Pravda obuhvaća i zakon Vlagyimir Monomacha II. nastao između 1113. i 1125. te još neke propise ruskih knezova iz 11. i 12. stoljeća. Ruskaja pravda temelji se na starom ruskom i slavenskom običajnom pravu te bugarskom Zakonu sudnjem ljudem. Vidi opširnije: Aleksandr Aleksandrovič Zimin, $K$ istorii teksta Kratkoj redakcii Ruskoj Pravdy (Moskva: 1954.); Ivan D. Beljaev, Istorija russkogo zakonodatel'stva (Moskva: 1879., reprint izd. 1999.); Lev Vladimirovič Čerepnin, Obščestvenno-političeskie otnošenija v Drevnej Rusi i Russkaja Pravda, v knige Drevnerusskoe gosudarstvo i ego meždunarodnoe značenie (Moskva: 1938.).

23 Vidi: Serafim Vladimirovič Juškov, Russkaja Pravda - proishoždenie, istočniki, ee značenie (Moskva: 1950.); Nikolai Vasilevič Kalačov, Predvaritel'nye ţridičeskie svedenija dlja polnogo ob"jasnenija Russkoj Pravdy (St. Petersburg: 1880.); Mikhail Borisovič Sverdlov, Ot Zakona Russkogo k Russkoj Pravde (Moskva: 1988.); Tihomirov, Mikhael Nikolaevič, Posobie dlja izučenija Russkoj Pravdy, Moskva: 1953.). 
predvidio je taj vid odgovornosti za kuću (čl. 71.), za selo (čl. 20., 77., 99., 111., 145. i 169.), grad (čl. 169.) te za područje (čl. 58., 100., 126., 158. i 191.). ${ }^{24}$

\subsection{Klič, zaklič}

Sudski postupak pokretao je tužitelj, osim u imovinskim stvarima gdje je postojao, tzv. klič ili povik, kod Rusa zaklič, kada je tužitelj kao vlasnik stvari na nekome trgu javno objavio krađu svoje stvari i pokrenuo istragu protiv lopova. Sličan način pokretanja spora se kod Čeha i Slovaka nazivao krik, u Poljičkom statutu vapaj. ${ }^{25}$ Sličan je bio i tipični slavenski institut svoda koji Ruskaja pravda regulira u $\S 14$. skraćena i u $\S 35$. proširena redakcija. Primjenjivao se radi otkrivanja lopova, tako da je vlasnik stvari ili najčešce stoke prepoznao svoga konja, kravu i sl. te je pozvao njezinoga posjednika na svod. Tada je pred sudom posjednik trebao imenovati osobu od koje je kupio spornu stvar ili životinju, a spomenuta je osoba imenovala prethodnoga posjednika itd. Ta je potraga trajala sve dok se ne bi utvrdio pravni temelj

24 Zakonik cara Dušana (Zakon blagovjernago cara Dušana) proglašen je na saboru u Skopju 1349. (135 članaka) i dopunjen s novih 66 članaka 1354. Temelji se na bizantskim zakonima (Sintagma, Proherios nomos, Nomos Georgikos) i na kanonima Pravoslavne Crkve (Nomokanon). Cilj mu je bio ujednačiti pravne sustave na područjima na kojima je Stefan Dušan ,Silni” (1331.-1355.) vladao (sebe je nazivao kraljem Srba, Bugara, Albanaca i Grka). Prvi je put objavljen 1795. u uratku Jovana Rajića tiskanome u Beču. Vidi inter alia: Jovan Rajić, Istorija raznih slovenskih narodov naipače Bolgar, Horvatov i Serbov (И. Раичъ: История разньихъ славенскихъ народовъ наипаче Болгаръ, Хорватовъ и Сербовъ). IV. (Wien, Виеннъ, Beč: 1795.); Biljana Marković, Dušanov zakonik (Beograd: Prosveta, 1986.); Biljana Marković, „O Dušanovom zakoniku”, u: Dušanov zakonik (Beograd: Narodna biblioteka Srbije u saradnji sa Odborom za izvore srpskog prava SANU i Jugoslovenskim udruženjem za multimediju, 1999.), pristup 21. ožujka 2006., http://www.dusanov-zakonik. co.yu/; Dimitrije Bogdanović, Dušanovo zakonodavstvo. Istorija srpskog naroda, I. (Beograd: Srpska književna zadruga, 1981.); Stojan Novaković, Zakonik Stefana Dušana cara srpskog 1349. i 1354. (Beograd: 1898.); Aleksandar Solovjev, Zakonodavstvo Stefana Dušana cara Srba i Grka (Skoplje: Skopsko naučno društvo, 1928.); Nikola Radojčić, Zakonik cara Stefana Dušana 1349. i 1354. godine (Novi Sad: Naučna izdanja Matice srpske. 3, 1950., odnosno Beograd: 1960.); Теодор Зигелъ, Законикъ Стефана Душана. (С. Петербургъ: 1870.); Александр Алексеевич Флоринский, Памятники законодатльной дъятельности Душана Царя Сербовъ и Грековъ (Киевъ: 1888.).

25 Poljički statut iz 1440. regulirao je pravne odnose u Poljičkoj Republici (ovaj naziv među prvima koristio talijanski putopisac Alberto Fortis 1774.). Republika je bila smještena između Mosora i Cetine, a od 13. stoljeća uživala je samoupravu. Zbog geostrateškoga položaja bila je metom čestih napada i pokušaja osvajanja, ali je samostalnost uspjela očuvati do 1807. (neki izvori tvrde do 1812.) kada ju je osvojio Napoleon. Za razliku od Dubrovačke Republike kao patricijske države, Poljička Republika bila je pučka tvorevina. Tako je Statutom propisano da narod izabire kneza i vladu (samo iz redova plemstva) te da o svim pitanjima odlučuje na saboru u Gatima i na seoskim zborovima (zborište). Stanovništvo Poljica bili su slobodni plemići i građani, kmetovi te vlasi. Plemstvo je bilo dvostrukoga podrijetla. Jedni su bili didići (potomci trojice braće utemeljitelja Poljica: Tišimira, Krešimira i Elema), a drugu je skupinu činila vlastela. Naziv didići povezan je s činjenicom da su pripadnici toga plemstva imali pravo nasljedstva nad imovinom svojih predaka (didovina), dok je vlastela bio naziv za plemstvo koje se naselilo iz drugih područja Hrvatske. Njih su u početku nazivali Ugričići (po Ugarskoj), a kasnije je postao općeprihvaćen naziv vlastela, kako bi ih se jasno razlikovalo od didića. 
stjecanja. Ako se vlasništvo ne bi moglo dokazati, onda je posjednik smatran tatom, a životinju je trebalo vratiti stvarnom vlasniku. ${ }^{26}$ Ovaj je institut bio poznat i u češkom, poljskom (svod, zuod) i srpskom pravu. Dušanov zakonik spominje ga u čl. 180. i 193.

\section{PRISEGA}

Pored VZ i Dušanov je zakonik poznavao institut porote za koji je Avakumović pokušao dokazati da je nastao skoro istodobno kao onaj u Engleskoj. ${ }^{27} \mathrm{Njegovo}$ gledište nije prihvaćeno, jer su porotnici u Vinodolskom i Dušanovu zakoniku bili tek neka vrsta dokaznog sredstva, svjedoci koji su prisegom potvrđivali istinitost prisege osobe na čijoj su strani prisegnuli. ${ }^{28}$ Zakon sudnjii ljudem i Ruskaja pravda također su zadržali dokazivanje putem stranaka i suprisežnika (coniuratores). Šira redakcija Ruskaje pravde u $\S 18$. propisala je da je za oslobođenje od optužbe potrebna prisega sedmorice suprisežnika (posluhi), dok su u slučaju stranaca bila dostatna dva suprisežnika. ${ }^{29}$ Pravda je poznavala i institut pristojbe za prisegu koja se plaćala pri polaganju prisege očišćenja i prodaje nekretnine. Dušanov je zakonik u kaznenopravnim predmetima propisao dokazivanje putem svjedoka, koji su u pojedinim slučajevima morali prisegnuti. ${ }^{30} \mathrm{U}$ dokaznom je postupku zakonik uveo porotu (porotnici se nazivaju duševnici), pored koje su dokaznu snagu imali lice (lat. corpus delicti), priznanje, prisega, ordalije, obličenije (hvatanje in flagranti), isprave, svod, svjedoci i udava. Suprisežnici su imali dvostranu dokaznu funkciju. Uglavnom su potvrđivali izjavu jedne od stranaka, a prema odredbi čl. 160. iznosili su samostalni iskaz o prijepornim činjenicama. U tim slučajevima nisu opravdavali stranku, već su davali izjave koje su bile važnije od izjave stranaka. Čl. 103. za kazneno djelo krađe propisuje dokazivanje svodom, a ako ono nije bilo moguće, onda se primjenjivala prisega uz pomagače. Kod težih kaznenih djela § 151. propisivao je da u poroti mora biti 24, kod djela srednje težine 12, a kod onih manje teških 6 porotnika. Oni su morali biti iz istoga staleža kojemu je pripadala i stranka uz koju su prisegnuli. Kod imovinskih sporova u vezi s međom svaka je od stranaka izabrala polovicu od ukupnoga broja porotnika i svjedoka. U sporovima između Srba i stranaca (mahom Dubrovčana i

26 Ilona Sz. Jónás, Középkori egyetemes történeti szöveggyüjtemény, Európa és Közel-Kelet IVXV. század, (Budapest: 1999.), pristup 27. travnja 2006., http://www.hik.hu/tankonyvtar/site/ books/b51/index.html.

27 Vidi: Jovan Avakumović, „Stara srpska porota poređena sa engleskom porotom”, Glas SKA, XLIV. (Beograd: 1894.), 1-36.

28 Vidi: Vladimir Bayer, Problem sudjelovanja nepravnika u suvremenom kaznenom sudovanju (Zagreb: 1940.). Usp. Čedomir V. Stevanović, Porotno suđenje u Srbiji krajem XIX. i početkom XX. veka, 125-132, 126, http://www.prafak.ni.ac.rs/files/zbornik/sadrzaj/zbornici/z03/09z03. pdf.

29 Kod Rusa je bilo i dokazivanje putem usijanoga željeza (lat. judicium ferri candetis) ili bacanja $u$ vodu (lat. judicium aquae frigidae). Ako optuženik za ubojstvo nije imao suprisežnike ili je bila riječ o krađi vrijednosti iznad pola grivne zlata, optuženi je nevinost trebao dokazati usijanim željezom (§ 21.).

30 Od svjedočenja su bili isključeni maloljetnici, žene, najamnici, osobe s mentalnih poteškoćama, sluge, siromasi, članovi obitelji, bliski srodnici, poslovni partneri, gluhi, nijemi, lažljivci i osobe koje nisu pravoslavne vjeroispovijesti. 
Sasa), dakle između pravoslavaca i katolika polovicu je porotnika birala jedna, a drugu polovicu druga stranka. Zakon je u § 153. propisao da ti duševnici odlučuju o krivici optuženika, nakon čega je sudac određivao kaznu. Porota se održavala u crkvi i tamo se polagala prisega pred svećenikom. No, ako se nakon prisege kod stranke pronašao corpus delicti, onda su se svi njezini suprisežnici imali kazniti novčanom kaznom od 1.000 perpera, njima se više nije moglo vjerovati, nisu se mogli ženiti, niti se bilo tko iz njihove obitelji mogao vjenčati (§154.).

Poljički je statut regulirao i institut porotništva (conjuratores) kao dokaznoga sredstva. Suprisežnici su polagali prisegu zajedno s optuženim ili tužiteljem jamčeći za stranku, a ne za njegovo djelo. Postojali su i porotnici - prisežnici u Gornjim Poljicima, koji su kao zaprisegnuti vijećnici rješavali manje sporove po selima.

Crnogorski Zakonik knjaza Danila iz 1855. u čl. 87. predviđao je dokazivanje putem svjedoka i prisege: Najposlije ostaje da jedan i drugi nađu za sebe četir poštena čoeka, koji će se zakleti; koji li uzima više poštenije ljudi, da se za njega zakunu, onaj dobija razlog i pravicu.

Osmanlije su ukinuli institut porote, ali je prisega ostala dokaznim sredstvom. Primijenjivali su ga i šerijatski sudovi koji su pet stotina godina djelovali na području Balkana (do kraja Drugoga svjetskoga rata), a nakon okupacije Bosne i Hercegovine postali su i sastavnim dijelom austro-ugarskoga sudskog sustava. Ovi su sudovi poznavali prisegu (jemin), odbijanje davanja prisege (jeminden mukul) i saslušavanje stranke nakon polaganja prisege (tahkimi hal). ${ }^{31} \mathrm{~S}$ obzirom na to da je u islamskom pravu izricanje kazne moguće samo u slučaju namjernoga počinjenja kaznenog djela i postojanja svijesti počinitelja o tome da svojom radnjom čini kazneno djelo, prisegom je mogao opovrgnuti nakanu i sposobnost prepoznavanja značenja djela. Na južnoslavenskome području naseljenom muslimanskim pučanstvom u 19. stoljeću primijenjivan je turski zakon Medžele čiji je § 1819. propisivao da sud odbije tužbeni zahtjev (kazai terk) u slučaju polaganja tuženikove prisege pred sudom i tužiteljeva odbijanja da zaprisegne. Ako je pak tuženik otklonio mogućnost davanja prisege, onda ga je sud proglašavao krivim (kazai-ilazum). ${ }^{32}$

\section{PRISEGA KOD ALBANSKIH I ROMSKIH ETNIČKIH SUDOVA}

Albanci i vlaški Romi i danas imaju svoje etničke sudove, od kojih albanski sude na temelju zbirke običajnoga prava Kanuni i Lekë Dukagjinit (KLD), a romski „na temelju pravičnosti” bez pisanoga zakona. U oba se sudska postupka dokazivanje uvelike temelji na prisezi. Porota, dakle ustanova suprisežnika iscrpno je uređena KLD-om. Albanci su mogli tražiti od protustranke polaganje prisege ako bi tko posumnjao u nekoga da je počinio kazneno djelo na njegovu štetu. Tada je optuženik sam ili zajedno s porotnicima (najviše 24) prisegnuo da nije kriv te se time „očistio" od sumnjičenja. Prisega se koristila i pri davanju časne riječi (besa). To se činilo se

31 Vidi: László Heka, „A sari’a jog fejlődése és alkalmazása a délszláv térségben”, Acta Universitatis Szegediensis. Acta Juridica et Politica t. 68, fasc. 10 (2006).

32 László Heka, A szláv népek joga (Szeged: Pólay Elemér Alapítvány Tansegédletei, 1940.), 5960 . 
na propisanom mjestu (crkvi) dodirivanjem svete relikvije (obično raspela ili Svetoga pisma), čime je prisežnik pozivao Boga kao svjedoka da govori istinu (§ 531.-532.). Prisega na kamen međaš bila je uobičajena kod zemljišnih sporova i tada je samo optuženik mogao davati prisegu kako bi se oslobodio optužbe (§ 539.). Pored ove dvije vrste postojale su prisege i na obiteljski dom (§ 558.-564.), i na glave sinova (otac je prisegnuo po cijenu života svojih sinova, § 565.-568.), odnosno prisega ne znam koja je također okončavala spor (\$569.-588.). ${ }^{33}$ Protiv prisege nije bilo mjesta prizivu, dakle njome se okončavao spor.

Polagala se ne samo u kaznenim predmetima i u imovinskim sporovima, nego i kod kupoprodaje. U tom potonjem slučaju rješavala je spor kada je prodavatelj osporavao primitak kapare, a kupac to nije mogao dokazati putem svjedoka (§ 462.).

Ako je zakon propisivao ustrojavanje porote, onda je njezin sastav propisivao sud (vijeće staraca) tako što imenovao polovicu porotnika, dok je drugu polovicu davao „vlasnik” prisege. Njezina je zadaća da polaganjem prisege „spasi stranku od problema" (§ 1044.). Prvo ju je polagao optuženik, a nakon njega su slijedili srodnici te naposljetku suprisežnici koje je odredio sud (§ 1076.). Prisegnuti su mogli samo muškarci (ali su od prisege bili isključeni oni članovi zajednice koji su osuđeni za lažnu prisegu), koji nisu bili u lošim odnosima ni s jednom od stranaka, koji su bili nepodmitljivi, sposobni prepoznati kazneno djelo i njegova počinitelja te nisu stajali pod prisegom (§ 1045.). Od prisege su bile izuzeti žene i djeca (§ 561.). Župnik je samo iznimno polagao prisegu $\mathrm{i}$ tada je njegova prisega vrijedila koliko i prisega 24 porotnika, dok je prisega bajraktara (vođe bajraka, zajednice koja je išla u rat pod jednom zastavom) bila istovjetna s prisegom 12 porotnika. Oni su prije davanja prisege mogli preispitati slučaj i odgoditi prisegu do šest mjeseci, a kod najtežih kaznenih djela čak i godinama. Ako je i samo jedan od porotnika odbijao prisegnuti, onda se „vlasnik” prisege nije uspijevao „očistiti” od optužbe (§ 1066.). Pored porote prisegnuti je trebalo i vijeće staraca da će suditi pošteno (§ 1031.).

Pri davanju prisege (kao i kod krvne osvete) su prisežnici pojeli kruh, time su posvjedočili nevinost optuženika i potvrdili svoju prisegu (§ 1069.), a ako nisu pojeli kruh onda su „vlasnika” prisege proglasili krivim (§ 1070.).

Lažna prisega se strogo kažnjavala. U slučaju krađe trebalo je isplatiti dvostruki iznos ukradene stvari i nastale troškove (minimalno jedno janje). Kada su za djelo svjedočila 24 porotnika kazna je bila 100 ovaca i jedan vol te 500 groševa globe. Davatelj lažne prisege trebao je zamoliti crkveno odrješenje te je svaki od porotnika morao platiti 500 groševa kazne za oskvrnuće crkve (§ 592.). Međutim, u slučaju prolijevanja krvi ona je dovodila do krvne osvete.

Sudovanje vlaških Roma naziva se romani kris i pokazuje puno sličnosti s albanskim izabranim sudom. Sudi samo u međusobnim sporovima vlaških Roma i djeluje usporedno s državnim sudovima (točnije bez znanja državnih sudova). Riječ je o nekoj vrsti mirovnih vijeća, jer je cilj sudovanja pomiriti Rome koji imaju problem između sebe. Suci nisu pravnici, nego osobe od autoriteta koje izabiru stranke, a nema

33 László Heka, „Vallási és politikai konfliktusok a délszláv térségben. Kanun i Lekë Dukagjinit (Az albán szokásjog)", Acta Universitatis Szegediensis. Acta Juridica et Politica t. 67, fasc. 10 (2005): 37-38. 
pisanog zakona, nego se ,presuda" donosi na temelju pravednosti.

Na početku krisa svi sudionici u postupku i svjedoci prisežu (solax) i obvezuju se kako neće jesti ni piti sve dok ne donesu ,presudu”. ${ }^{34}$ Oblik se prisege razlikuje od zemlje do zemlje. U Slovačkoj i Mađarskoj priseže se na raspelo ili svetu sliku, a na Balkanu u crkvi. Prisega obvezuje stranke, pa ako neka od njih, ili pak koji od svjedoka ne prisegne, onda je time spor riješen. Nekada se svjedok toliko uplaši od lažne prisege (uvriježeno je među njima mišljenje da lažna prisega znači velike probleme), pa ju odbije dati. Stojka ističe kako vlaški Romi, radije plate jedan milijun, nego li otvore usta na prisegu. ${ }^{35}$ Nakon proglašenja sudske odluke stranke se rukuju, a zatim opet prisegnu i potvrđuju da prihvaćaju odluku i ostaju i dalje prijatelji. Lažnu prisegu i oni kažnjavaju, nekada čak i isključenjem iz zajednice (mageripo) što je najveća kazna i traje najviše do sedam godina.

\section{ZAKLJUČAK}

VZ najstariji je hrvatski i jedan od najstarijih slavenskih zakona, koji se može svrstati u red stožernih europskih srednjovjekovnih pravnih propisa. Riječ je zborniku običajnoga prava napisanom hrvatskom glagoljicom, koji obuhvaća njemačke, talijanske i slavenske pravne institute. Ima neprocjenjivu vrijednost kao svjedočanstvo hrvatskoga nacionalnog identiteta, jezika, pisma i kulture.

U parničnom je postupku zakon propisivao dokazivanje putem svjedoka (mogle su svjedočiti i žene, ako nije bilo muških svjedoka), a u njihovu nedostatku, polaganje prisege očišćenja. Ona je dolazila u obzir samo onda, ako se meritorna činjenica nije mogla dokazati drukčije i obično je prisegu polagao tuženik. S obzirom na to da je teret dokazivanja bio na tužitelju, on je svakako nastojao osigurati svjedoke, jer se u protivnom tuženi polaganjem prisege oslobađao od odgovornosti. To je bilo vrlo povoljno rješenje za tuženika, pa se nije koristio mogućnosti da ponudi protusvjedoke, propisanom člankom 47. Kod svjedočenja je bitan element bio klič, naime povik pomagajte u cilju da netko (uključujući i oštećenoga) uhvati počinitelja pri krađi (lat. in flagranti), ali i kao javno upućivanje na počinjenje protupravnoga djela. Njegov je iskaz bio vjerodostojan ako je prisegnuo pred sudom da je prepoznao počinitelja. Kod pojedinih težih kaznenih djela tražilo se i sudjelovanje suprisežnika (porotnika) koji su u korist optuženoga (a u slučaju silovanja u korist tužiteljice) svjedočili o nevinosti obveznika prisege. Prisegnulo je najmanje pet (kod lakših kaznenih djela), a najviše 49 (kod ubojstva) porotnika, a u njihovu nedostatku prisegnuo je on sam onoliko puta koliko mu je nedostajalo porotnika.

Prisega kao dokazno sredstvo bila je poznata i u onodobnim slavenskim pravnim propisima.

Dušanov zakonik poznavao je institut porote kao svjedoka koji su potvrđivali istinitost prisege osobe na čijoj su strani prisizali. No, katkad su porotnici iznosili i samostalni iskaz o prijepornim činjenicama (čl. 160.) te tada nisu opravdavali stranku,

34 http://www.gipsy-info.com/grp/yu/streit.cds?lang=yu\&grp=streit, pristup 11. studenog 2019.

35 Péter Stojka, „A Cigány Törvény”, u: Baxtalo Drom, 1997, Italija, pristup 20. svibnja 2006. http://www.amarodrom.hu/archivum/2002/07/28.html. 
već su davali izjave koje su bile važniji dokaz od izjave stranaka. Bugarski Zakon sudnjii ljudem i Ruskaja pravda također su zadržali dokazivanje putem stranaka i suprisežnika (lat. coniuratores). Šira redakcija Ruskaje pravde u $\S 18$. propisala je da je za oslobođenje od optužbe potrebna prisega sedmorice suprisežnika (posluhi), dok su u slučaju stranaca bila dostatna dva suprisežnika. Poljički statut također je regulirao institut porotništva (conjuratores) kao dokaznoga sredstva. Suprisežnici su polagali prisegu zajedno s optuženim ili tužiteljem jamčeći za stranku, a ne za njegovo djelo. Postojali su i porotnici prisežnici u Gornjim Poljicima, koji su kao zaprisegnuti vijećnici rješavali manje sporove po selima.

Crnogorski Zakonik knjaza Danila iz 1855. u čl. 87. predviđao je dokazivanje putem svjedoka i prisege. Osmanlije su na južnoslavenskom području ukinuli institut porote, ali je prisega ostala dokaznim sredstvom. Primjenjivali su ga i šerijatski sudovi koji su pet stotina godina djelovali na području Balkana (do kraja Drugoga svjetskoga rata).

Danas je prisega dokazno sredstvo u etničkom sudovanju Albanaca i vlaških Roma.

\section{LITERATURA}

1. Antal, Tamás. „The Legal Status of Judges in the German 'Spiegels' and in the Medieval English Common Law". U: Schwabenspiegel-Forschung im Donaugebiet. Hrsg. von Elemér Balogh. Berlin: Walter de Gruyter, 2015., 73-83.

2. Avakumović, Jovan. „Stara srpska porota poređena sa engleskom porotom”. Glas SKA, 44 (1894): 1-36.

3. Badó, Attila.: A laikus bíráskodás. U: Bevezetés a jogszociológiába, Badó, Attila-Loss, Sándor-H. Szilágyi, István-Zombor, Ferenc (szerk.). Miskolc: Bíbor Kiadó, 1999.

4. Badó, Attila. „Esküdtszéki ítéletek. Studio Batiq, 2004.;

5. Bartulović, Željko. „Pravna ostavština”. U: Putovima Frankopana, Frankopanska baština u Primorsko-goranskoj županiji, ur. Ines Srdoč Konestra i Saša Potočnjak. Rijeka: Primorsko-goranska županija, 2018., 427-428.

6. Bayer, Vladimir. Problem sudjelovanja nepravnika u suvremenom kaznenom sudovanju. Zagreb: 1940.

7. Beljaev, Ivan D. Istorija russkogo zakonodatel'stva, 1879. Reprint izd. Moskva: Nauka 1999.

8. Bodjanski, Osip. Vinodol'skyj zakon 1280. g. v podlinnike-perevod s serbskago. Ćtenija v Imperatorskom Obščestve istorii i drevnostej pri Moskovskom universitete. Moskva: 1846.

9. Bogdanović, Dimitrije. Dušanovo zakonodavstvo. Istorija srpskog naroda, I. Beograd: Srpska književna zadruga, 1981.

10. Bogović, Mile. Vinodol i njegova Crkva od Vinodolskoga zakona do naših dana. Rijeka: Riječka nadbiskupija, 2015.

11. Bratulić, Josip, ur. Vinodolski zakon 1288. faksimil, diplomatičko izdanje, kritički tekst, tumačenje, rječnik. Zagreb: Nacionalna i sveučilišna biblioteka - Jugoslavenska akademija znanosti i umjetnosti - Pravni fakultet Zagreb, Globus, 1988. http://www. vinodol.org/uvod_1/doku/vz_bra.pdf

12. Breitenfeld, Fedor. Dva poljska prijevoda Vinodolskoga zakona, 1856. i 1935. Zagreb: 1936. 
13. Budrović, Dominik O. P. „Da li je kriva zakletva uviek težak grieh“. Bogoslovska motra 4: 49-58. file://C:/Users/Felhaszn\%C3\%A11\%C3\%B3/Downloads/BS_1_43_Budrovic. pdf.

14. Čerepnin, Lev Vladimirovič. Obščestvenno-političeskie otnošenija v Drevnej Rusi $i$ Russkaja Pravda, v knige Drevnerusskoe gosudarstvo i ego meždunarodnoe značenie. Moskva: 1938.

15. Feleky, Gábor-Lőrinczi, János-Badó, Attila. „Empirijsko istraživanje porotnog sustava u Mađarskoj”. Zbornik Pravnog fakulteta Sveučilišta u Rijeci 39, (3) (2018.): 1287-1318.

16. Florinskii, Aleksandr Alekseevič (Флоринский, Александр Алексеевич). Pamjatniki zakonodatljnoj dejateljnosti Dušana carja Serbov i Grekov (Памятники законодатльной дъятельности Душана Царя Сербовъ и Грековъ). Кiеv (Киевъ): 1888.

17. Heka, László. „A sari’a jog fejlődése és alkalmazása a délszláv térségben”. Acta Universitatis Szegediensis. Acta Juridica et Politica 68, (2006): Fasc. 10.

18. Heka, László. A szláv népek joga. Szeged: Pólay Elemér Alapítvány Tansegédletei, 2006.

19. Heka, László. „Der „Eid” im Beweisverfahren der südslawischen Region (Vergleichende Studie)“. U: Legal Transitions. Development of Law in Formerly Socialist States and the Challenges of the European Union. Pólay Elemér Alapítvány Könyvtára. Szeged: 2007., 115-122.

20. Heka, László. „Vallási és politikai konfliktusok a délszláv térségben. Kanun i Lekë Dukagjinit (Az albán szokásjog)". Acta Universitatis Szegediensis. Acta Juridica et Politica 67, (2005): Fasc. 10.

21. Heka, László. Vallási jogrendszerek. Pólay Elemér Alapitvány Tansegédletei. Szeged: 2012.

22. Jagić, Vatroslav. Zakon vinodol'skij, podlinnyj tekst s russkim perevodom, kritičeskinii zamečanljami i objasnenijami, Obščestvo ljubitelej drevnej pis'mennosti. S. Peterburg: 1880. 1-152.

23. Janković, Dragoslav. Istorija država i prava naroda Jugoslavije. Beograd: Naučna knjiga, 1960.

24. Juškov, Serafim Vladimirovič. Russkaja Pravda - proishoždenie, istočniki, ee značenie. Moskva: 1950.

25. Kalačov, Nikolai Vasilevič. Predvaritel'nye tridičeskie svedenija dlja polnogo ob"jasnenija Russkoj Pravdy. St. Petersburg: 1880.

26. Kalven, Harry-Zeisel, Hans. The American Jury System. New Haven: Yale University Press, 1966.

27. Kostrenčić, Marko. Nacrt historije hrvatske države i hrvatskog prava. Zagreb: Školska knjiga, 1956.

28. Kostrenčić, Marko. „Vinodolski zakon”. Rad JAZU 227. Razredi filologičko-historički $i$ filosofičko-juridički. Knj. 99, (1923),163 (54) - 176 (67).

29. Laginja Matko. „Vinodolski zakon”. Pravo 3 (1875):

30. Margetić, Lujo. „Hrvatski pravni običaji”. Arhivski vjesnik 37 (1994): 147-159.

31. Margetić, Lujo. „Iz vinodolske prošlosti”. Pravni izvori i rasprave. Rijeka i Zagreb: Liburnija i Školska knjiga, 1980., 149-166.

32. Margetić, Lujo. Vinodolski zakon 1288-1988. 3. izd. Novi Vinodolski: Naklada Kvarner, 2018.

33. Margetić, Lujo. Vinodolski zakon. Rijeka: Adamić, 2000.

34. Marković, Biljana. Dušanov zakonik. Beograd: Prosveta, 1986.

35. Marković, Biljana. „O Dušanovom zakoniku”. U: Dušanov zakonik. Beograd: Narodna biblioteka Srbije u saradnji sa Odborom za izvore srpskog prava SANU i Jugoslovenskim udruženjem za multimediju, 1999. http://www.dusanov-zakonik.co.yu/

36. Mažuranić, Antun. „Zakon vinodolski od lěta 1280”. Kolo knj. 3 (1843): 50-97.

37. Novaković, Stojan. Zakonik Stefana Dušana cara srpskog 1349. i 1354. Beograd: 1898. 
38. Radojčić, Nikola. Zakonik cara Stefana Dušana 1349. i 1354. godine. Novi Sad: Naučna izdanja Matice srpske, 1950.

39. Rajić, Jovan. Istorija raznih slovenskih narodov naipače Bolgar, Horvatov i Serbov (И. Раичъ: История разньихъ славенскихъ народовъ наипаче Болгаръ, Хорватовъ и Сербовъ). Wien: 1795.

40. Solovjev, Aleksandar. Zakonodavstvo Stefana Dušana cara Srba i Grka. Skoplje: Skopsko naučno društvo, 1928.

41. Stevanović, Čedomir V. Porotno suđenje u Srbiji krajem XIX. i početkom XX. Veka, 125132. Pristup 20. svibnja 2018. http://www.prafak.ni.ac.rs/files/zbornik/sadrzaj/zbornici/ z03/09z03.pdf.

42. Stojka Péter. „A Cigány Törvény”. U: Baxtalo Drom, 1997, Olaszország. Fordította: Rézmüves Melinda. Pristup 20. svibnja 2006. http://www.amarodrom.hu/ archivum/2002/07/28.html.

43. Sverdlov, Mikhail Borisovič. Ot Zakona Russkogo k Russkoj Pravde. Moskva: 1988.

44. Sz. Jónás, Ilona. Középkori egyetemes történeti szöveggyüjtemény, Európa és Közel-Kelet IV-XV. század, Budapest, 1999. Pristup 27. travnja 2006.http://www.hik.hu/tankonyvtar/ site/books/b51/index.html.

45. Tihomirov, Mikhael Nikolaevič. Posobie dlja izučenija Russkoj Pravdy. Moskva: 1953.

46. Uzelac, Alen. Istina u sudskom postupku. Zagreb: Pravni fakultet, 1997. Pristup 29. kolovoza 2018. http://www.alanuzelac.from.hr/pubs/D06Istina $\% 20 \% 20 \mathrm{u} \% 20$ sudskom\%20postupku.pdf

47. Zigelj, Teodor (Зигелъ, Теодор). Zakonik Stefana Dušana (Законикъ Стефана Душана). Sankt Peterburg (С. Петербургъ): 1870.

48. Zimin, Aleksandr Aleksandrovič. K istorii teksta Kratkoj redakcii Ruskoj Pravdy, Moskva: 1954. 


\section{László Heka*}

Summary

\section{THE OATH AS THE TOOL OF EVIDENCE IN THE CODE OF VINODOL}

The Code of Vinodol, the oldest Slavic code, was compiled in 1288. It can be classified as one of the important cornerstone in European medieval law. According to this particular code, the legal processes were accusatorial, oral and public. During the evidentiary process oath, mainly by the side of the accuser, was required. The accused party on the other hand could used oath in case of sexual violence. Later the oath of compurgators played an important role in the process. The number of compurgators ranged from 5 to 49 based on the seriousness of the crime. In case of sexual violence, compurgators swore to the innocence of the accused party. In absence of compurgators, the accused had to take as many oaths as many compurgators were lacking.

It is presumed that the institution of jury and the institutionalization of testimony and documentary evidence are the result of the development of medieval litigation and oaths. This study compares the evidence process of Code of Vinodol with other Slavic processes, with special regard to the role of oaths and compurgators.

Keywords: Code of Vinodol; oath; compurgators; evidentiary procedure; Ruskaja pravda.

\section{Zusammenfassung}

\section{EID ALS BEWEISMITTEL IM GESETZ VON VINODOL}

Das älteste kroatische Gesetz, Gesetz von Vinodol, gehört zu den ältesten slawischen geschriebenen Gesetzen. Es wurde am Tag der Heiligen Drei Könige, am Dienstag, den 6. Januar 1288 erlassen. Geschrieben in glagolitischer Schrift und in der kroatischen Sprache, sei das Gesetz nicht als Ansporn von Herrschern oder Feldherrn erlassen worden, sondern durch Absprache von den Gemeinden und Fürsten Vinodols. Insofern stellt es eine Vorschrift Gewohnheitsrechts dar, ausgeprägt durch besonderen Rechtsinhalt, der aus Bestimmungen Erb-, Straf-, Verfahrens-, sowie Verwaltungsrechts besteht. Trotz deutschen, italienischen und slawischen Rechtsinstituten, die in ihm vorhanden sind, verkörpert das Gesetz von Vinodol vor

* László Heka, Ph.D. Associate Professor, Faculty of Law, University of Szeged, Institute for Comparative Law and Legal Theory; heka@juris.u-szeged.hu. 
allem die kroatische Nationalidentität. Aus diesem Grunde kann es nicht nur als eine der auschlaggebenden Rechtsquellen betrachtet werden, sondern auch als Zeuge der kroatischen Sprache, Schrift und Kultur. Deswegen zählt es zu den wichtigsten europäischen mittelalterlichen Rechtsvorschriften, die in der Muttersprache verfasst wurden, zusammen mit Zakon sudnyj ljudem, Russkaja Prawda oder Sachsenspiegel, bzw. dem früher (601-925) erlassenen angelsächsischen Sammelband von Gewohnheitsrecht. Das Augenmerk in diesem Beitrag liegt auf Eid als Beweismittel im Zivilverfahren und auf die Weise wie es durch das Gesetz von Vinodol geregelt wurde im Vergleich zu anderen zeitgenössischen slawischen Gesetzen, die auch analysiert werden.

Schlüsselwörter: das Gesetz von Vinodol; Beweisverfahren; Strafen; Eid (rota); Schöffen; Miteidschwörende.

Riassunto

\section{IL GIURAMENTO COME MEZZO DI PROVA NELLA LEGGE DEL VINODOL}

La Legge del Vinodol è la più antica legge scritta croata ed una delle più antiche leggi slavene scritte. È stata adottata martedì 6 gennaio 1288 alla festa dei tre Re Magi ossia dell'Epifania. La specificità di essa sta nel fatto che non è stata creata con la volontà del sovrano o del signore feudale, ma con l'accordo tra i comuni di Vinodol e del principe, perciò è sostanzialmente un elenco del diritto consuetudinario locale. È stata scritta in glagolitico in lingua croata. È particolare anche per il contenuto giuridico, perché salvo le disposizioni del diritto sulle successioni, penale e processuale, regola pure le questioni appartenenti al diritto amministrativo. Purché contiene istituti giuridici tedeschi, italiani e slaveni, la Legge del Vinodol è portatrice dell'identità nazionale croata. Per questo motivo non la si osserva soltanto quale una delle fonti principali del diritto, ma anche come un testimone della lingua, dell'alfabeto e della cultura croata. Da più aspetti è legittimo inserirla tra i regolamenti medievali europei scritti in ligua madre, insieme al Zakon sudnjii ljudem, Ruskaju Pravdu e al Sachsenspiegel, cioè alla raccolta anglosassone del diritto consuetudinario sorta ancor prima (601-925).

In questo lavoro trattiamo del giuramento come mezzo di prova nel processo civile ed il modo in cui è stato regolato nella Legge del Vinodol, dando un'analisi comparata di questo mezzo di prova secondo le disposizioni di altre leggi slavene di quel tempo.

Parole chiave: Legge del Vinodol; procedimento probatorio; sanzioni; giuramento (rota); giuria; congiurati. 